San Jose State University

SJSU ScholarWorks

Master's Theses

Master's Theses and Graduate Research

1996

\title{
Light and plant orientation effects on pigment and reproductive patterns in Bossiella sp
}

Cassandra Roberts

San Jose State University

Follow this and additional works at: https://scholarworks.sjsu.edu/etd_theses

\section{Recommended Citation}

Roberts, Cassandra, "Light and plant orientation effects on pigment and reproductive patterns in Bossiella sp" (1996). Master's Theses. 1290.

DOI: https://doi.org/10.31979/etd.aypt-ym6n

https://scholarworks.sjsu.edu/etd_theses/1290

This Thesis is brought to you for free and open access by the Master's Theses and Graduate Research at SJSU ScholarWorks. It has been accepted for inclusion in Master's Theses by an authorized administrator of SJSU ScholarWorks. For more information, please contact scholarworks@sjsu.edu. 


\section{INFORMATION TO USERS}

This manuscript has been reproduced from the microfilm master. UMI films the text directly from the original or copy submitted. Thus, some thesis and dissertation copies are in typewriter face, while others may be from any type of computer printer.

The quality of this reproduction is dependent upon the quality of the copy submitted. Broken or indistinct print, colored or poor quality illustrations and photographs, print bleedthrough, substandard margins, and improper alignment can adversely affect reproduction.

In the unlikely event that the author did not send UMI a complete manuscript and there are missing pages, these will be noted. Also, if unauthorized copyright material had to be removed, a note will indicate the deletion.

Oversize materials (e.g., maps, drawings, charts) are reproduced by sectioning the original, beginning at the upper left-hand comer and continuing from left to right in equal sections with small overlaps. Each original is also photographed in one exposure and is included in reduced form at the back of the book.

Photographs included in the original manuscript have been reproduced xerographically in this copy. Higher quality $6 " \times$ " black and white photographic prints are available for any photographs or illustrations appearing in this copy for an additional charge. Contact UMI directly to order.

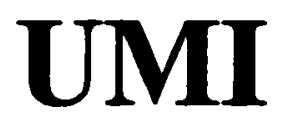





\title{
LIGHT AND PLANT ORIENTATION EFFECTS ON PIGMENT AND REPRODUCTIVE PATTERNS IN \\ BOSSIELLA sp.
}

\author{
A Thesis \\ presented to \\ The Faculty of the Department of Biology \\ San Jose State University \\ In Partial Fulfillment \\ of the Requirements for the Degree \\ Master of Science
}

By

Cassandra Roberts

August 1996 
UMI Number: 1381317

UMI Microform 1381317

Copyright 1996, by UMI Company. All rights reserved.

This microform edition is protected against unauthorized copying under Title 17, United States Code.

\section{UMI \\ 300 North Zeeb Road \\ Ann Arbor, MI 48103}


(C) 1996

\section{Cassandra Roberts}

\section{ALL RIGHTS RESERVED}


APPROVED FOR THE DEPARTMENT OF BIOLOGY

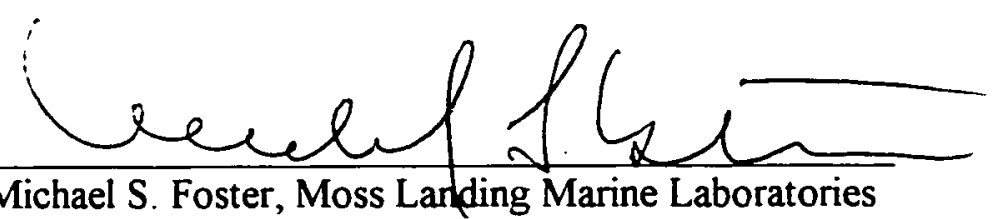

Dr. Michael S. Foster, Moss Landing Marine Laboratories

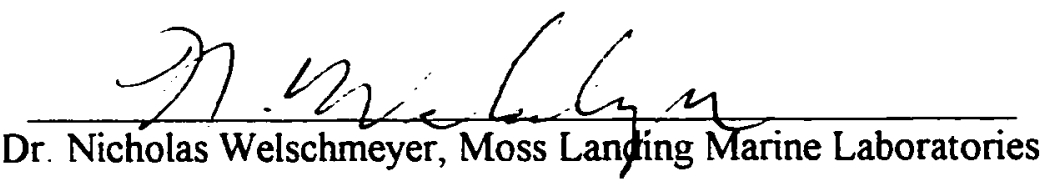

Webcam Broeurow

Dr. William Broenkow, Moss Landing Marine Laboratories

APPROVED FOR THE UNIVERSITY

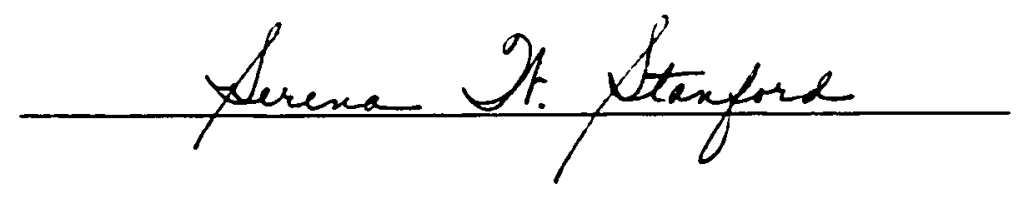




\section{ABSTRACT \\ LIGHT AND PLANT ORIENTATION EFFECTS ON \\ PIGMENT AND REPRODUCTIVE PATTERNS IN \\ BOSSIELLA sp.}

by Cassandra Roberts

Effects of light intensity on pigment concentration are critical to understanding how natural conditions affect photosynthetic pigments. The calcareous alga, Bossiella californica schmittii, has a unique dorsi-ventral orientation. Natural collections were used to investigate changes in phycoerythrin between plant surface and depth. The dorsal surfaces of plants collected from two depths contained significantly more phycoerythrin than the ventral surfaces, but there were no significant differences in phycoerythrin of the same surface between depths. To investigate changes in chlorophyll $a$ and phycoerythrin over time and different light intensities, plant surfaces were placed in unshaded and shaded conditions. Both pigments in the plant surfaces increased significantly under shaded conditicns after ten weeks. These results indicate that pigments in Bossiella increase with decreasing irradiance in ten weeks, and plant orientation affects patterns of pigment distribution. Orientation may also influence surfaces on which conceptacle development occurs as several plants developed conceptacles on upturned ventral surfaces. 


\section{Acknowledgments}

This study could not have been completed without the help of many people. I would first like to thank Dr. Mike Foster, my advisor and friend, for his patience. encouragement, and wisdom given to me while at Moss Landing. Dr. Nicholas Welschmeyer for his hours spent in the lab with me, interest in my project and the use of his lab and instruments during the analysis portion of my study. Dr. William Broenkow, for his time and comments on my thesis. John Heine for running a great dive program and providing us with all the essentials for subtidal work. I would also like to thank John Oliver for those reality checks on life and providing the bigger picture.

I would like to thank Brenda Konar, Diana Steller, and Karen Crow for many years of close friendship and support throughout my time at Moss Landing. I feel very fortunate to have friends like you. Graduate work can never be accomplished without the help of others. I would like to thank my dive buddies James Downing, George Leonard, Lawrence Honma, Ross Clark, and Matt Edwards for the many hours of fun we had underwater and sharing in all the work ( 3 dive days) and rewards (Taco Bell) that come with subtidal theses. I will fondly remember "having" to dive four to five days per week.

Another one of the many reasons why MLML is so special is because of the staff. I would like to thank Gail Johnston, Sheila Baldridge, Lynn McMasters, Sandy Yarborough, Irene Chung, Aldo DeRosa, Sandi O'Neill, and all the Marine Operations staff for really making the our lab, with or without permanent buildings, the incredible place that it is for research and education.

I would like to thank the Dr. Earl H. and Ethel M. Myers Oceanographic and Marine Biology Trust Fund and the Packard Foundation for financial support. Lastly, I would like to thank Mark Stephanson of the State Mussel Watch Program and Rusty Fairey of the Bay Protection and Toxic Cleanup Program for the financial support, resources, and encouragement they provided for myself and many other students over the years at Moss Landing. 
TABLE OF CONTENTS

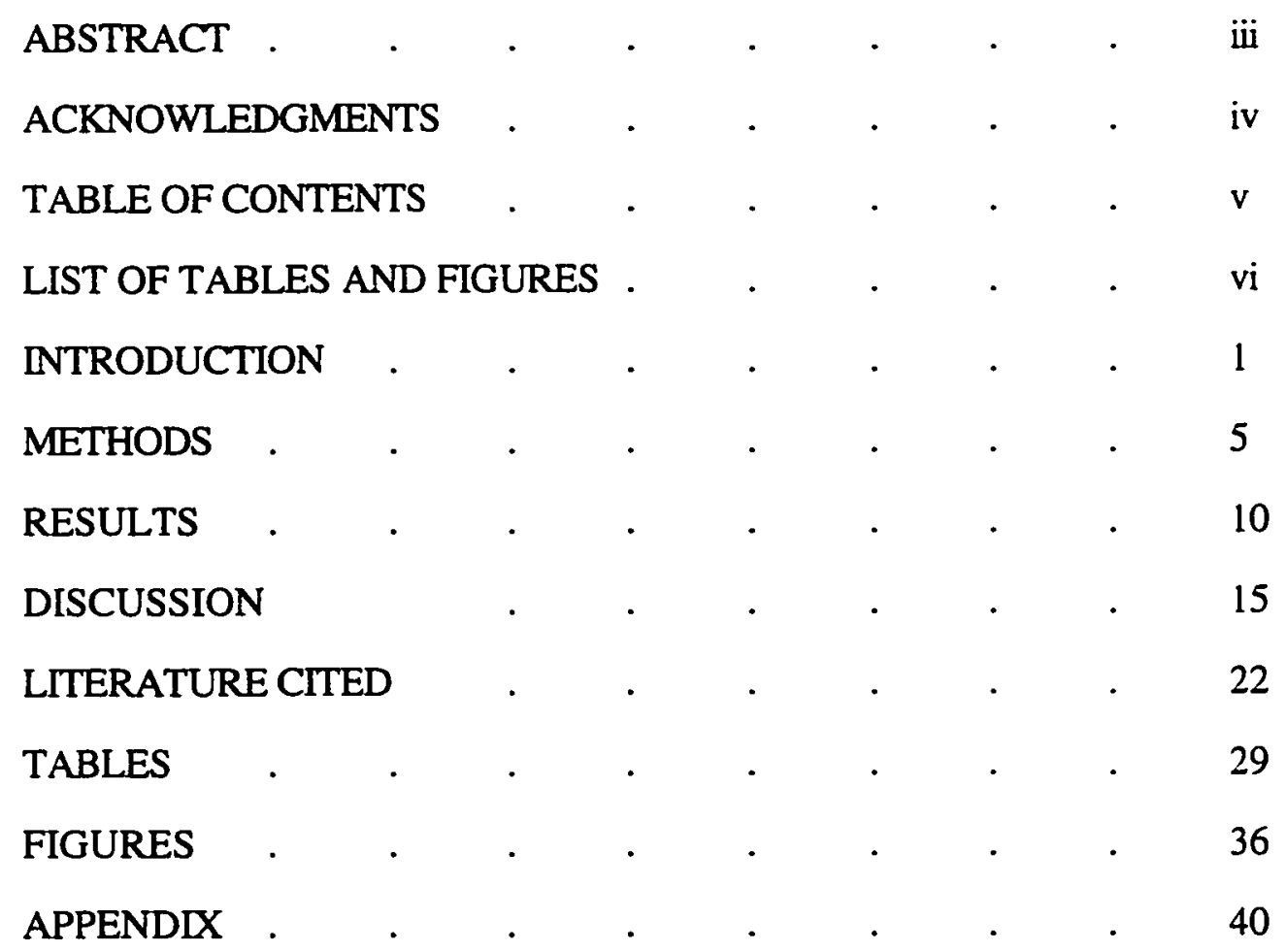




\section{LIST OF TABLES AND FIGURES}

Table \# Title

Page \#

$\begin{array}{ll}\text { 1. Percent surface irradiance } & 29\end{array}$

2. Phycoerythrin fluorescence from natural collections 30

3. Two-factor ANOVA for phycoerythrin at $16 \mathrm{~m}$

4. One-factor ANOVA for phycoerythrin at $16 \mathrm{~m}$ and $7 \mathrm{~m}$ sites 32

5. Two-factor ANOVA for chlorophyll $a$ at $16 \mathrm{~m}$

6. One-factor ANOVA for chlorophyll $a$ in $16 \mathrm{~m}$ and $7 \mathrm{~m}$ sites 34

7. Percent of reproductive plants in field experiments 35

Figure \#

1. Mean precision of phycoerythrin 36

2. Changes in phycoerythrin over time and light levels 37

3. Changes in chlorophyll $a$ over time and light levels 38

4. Ratio of phycoerythrin to chlorophyll $a \quad 39$ 


\section{Introduction}

The light harvesting pigments found in all photosynthetic plants convert photons into chemical energy for photosynthesis (Haxo and Blinks 1950, Rowen 1989). Accessory pigments extend the absorption spectra of a plant by using wavelengths of light not absorbed by chlorophyll $a$ (Duysens 1951, Glazer 1985, Gantt 1990, Algarra et al. 1991). One important group of light-harvesting accessory pigments in marine macroalgae is phycobiliproteins found in the Phyla Rhodophyta, Cryptophyta, and Cyanophyta (Larkum and Barrett 1983).

Phycobiliproteins are aggregates of chromophores covalently bonded to an apoprotein. They serve as primary light-gathering antennae, greatly extending the range over which light is absorbed which can be from 490 to $650 \mathrm{~nm}$ (Larkum and Weyrauch 1977, Larkum and Barrett 1983). Phycobilisomes (PBS) are macromolecular complexes which are made of phycobiliproteins bound together by linker polypeptides (apoproteins). In Rhodophytes and Cryptophytes, the PBS is functionally analogous to the light-gathering complexes containing chlorophyll $a$ and $b$ in green plants (Gantt 1981, Glazer 1985). Energy is absorbed by the pigment and transferred, via a chain of biliproteins, to the reaction center of the photosynthetic membrane (Gantt 1981, Glazer 1984. 1985, Scheer 1986). The absorption spectra for phycobiliproteins are in the green wavelength 'but may vary for the specific phycobilin (Gantt 1990). Red algae contain combinations of these biliproteins that act as light harvesting mechanisms for the photosystem two (PSII) reaction center in photosynthesis (Gantt 1990).

Photoacclimation describes responses by plants to changes in photon flux density or spectral distribution (Falkowski and LaRoache 1991). Phycobilisomes are adaptable structures influenced quantitatively and qualitatively by various environmental factors, especially total irradiance, spectral distribution of the irradiance, 
and nutrient conditions (Wehrmeyer 1988). With increasing water depth, algae receive less light and different wavelengths of photosynthetically active radiation (PAR). The concentration of accessory pigments in marine algae increases with decreasing light levels (Dring 1981, Dring 1986, Ramus et al. 1976, Rosenberg and Ramus 1982, Ramus 1983). Lopez-Figueroa and Niell (1990) found short term increases in phycoerythrin concentration in plants grown under different light intensities in the laboratory, indicating that temporal scale may be important in understanding variations in pigment concentrations. While laboratory studies alone may not accurately simulate field conditions, in situ studies of light effects on pigment concentration are difficult because light quality and quantity change simultaneously (Dring 1981, Saffo 1987).

Decreased phycoerythrin concentration has also been correlated with low ambient nitrogen (Rosenberg and Ramus 1982, Kana and Gilbert 1987). Phycoerythrin concentrations in both Neoagardiella baileyi (Kutz) Wynne \& Taylor (DeBoer and Ryther 1978) and Gracilaria folifera (Forsskal) Borgesen (La Pointe and Ryther 1979, La Pointe 1981) increased when nitrates were increased in the laboratory. Phycoerythrin concentration may change seasonally (Rhee and Briggs 1977, Rosenberg and Ramus 1982). Pigment content in G. foliifera was higher during the winter, (low growth) than in the summer (Rosenberg and Ramus 1982). Photosynthetic pigment concentrations also are affected by morphology, optical transparency of the thallus, and growth rate (Littler and Arnold 1980, Ramus 1983).

Bossiella californica ssp. schmittii (Manza) Johans. (hereafter refered to as Bossiella) is a calcified, subtidal red alga found in the understory canopy of Macrocystis pyrifera (L.) C. Ag. forests along the western coast of the United States from British Columbia to San Diego Co., California (Abbott and Hollenberg 1976). In Stillwater Cove, Carmel Bay, California, Bossiella occurs from 9 to over $20 \mathrm{~m}$ deep 
(Foster and Schiel 1985). It occurs on horizontal rocky outcrops with other geniculate and nongeniculate corallines but is the dominant geniculate coralline on vertical walls at these depths (Konar and Foster 1992). It has a unique dorsi-ventral orientation, and changing this orientation alters the pigment concentration between the two surfaces of the thallus (Roberts pers. obs.). The dorsal surface of Bossiella is darker while the ventral surface is lighter. In a preliminary study, the previously ventral surface became darker and the previously dorsal surface became lighter when the orienation was reversed. This response is atypical of photosynthetic pigment responses to light intensity in other algae and "shade-adapted" terrestrial plants, which generally increase their pigment concentration in response to low light conditions (Beer and Levy 1983, Algarra and Niell 1990).

The reproductive structures of Bossiella are found in conceptacles on the dorsal surface and are unique to the genus in originating in cortical rather than medullary tissue as in other geniculate corallines (Johansen 1973). It is not known whether light intensity or plant orientation affects conceptacle development. Preliminary data suggested that upturned ventral surfaces become reproductive when exposed to increased light whereas conceptacles have never been recorded on the ventral surface of plants examined.

If accessory pigments increase when light is decreased, the ventral surface of Bossiella should contain more pigment than the dorsal surface, but this has not been quantified between surfaces and among depths. If light intensity affects pigment production, differences should be found between the dorsal and ventral surfaces of plants collected at different depths in the field. The plants at deeper depths should have more phycoerythrin in both the dorsal and ventral surfaces. If the alga is placed at a fixed depth and both surfaces exposed to similar light intensities, both the dorsal and 
ventral surfaces should produce similar concentrations of phycoerythrin and chlorophyll $a$ if light intensity regulates pigment concentration. Manipulations of light intensity in the field at a fixed depth would allow a test of the laboratory observations that light intensity affects accessory pigment concentrations. Based on these observations and using a manipulative field study, I examined how light intensity and plant orientation affect Bossiella 's pigment concentration in the field.

The objectives of this study were to 1) determine if there is a difference in phycoerythrin concentration among depths, and between the dorsal and ventral surfaces of Bossiella, 2) determine if and how phycoerythrin and chlorophyll a concentrations in the dorsal and ventral surfaces differ over time when light intensities are manipulated in the field, 3) determine if there is a relationship between both pigment ratios under different light intensities and plant surface orientation, and 4) examine the effect of light intensity and orientation on conceptacle development. 


\section{Methods}

Study site

Field experiments and natural collections were done in Stillwater Cove, in the northern end of Carmel Bay, CA, USA ( $\left.36^{\circ} 34^{\prime} \mathrm{N}, 121^{\circ} 56^{\prime} \mathrm{W}\right)$. The surface canopy of Macrocystis pyrifera, a subsurface canopy of Pterygophora californica Ruprecht varies seasonally in Stillwater Cove, while the understory is largely dominated by geniculate coralline algae (Reed and Foster 1984). The cove is protected from large northerly swells associated with winter storms as well as predominant strong northwesterly winds (Foster and Schiel 1985).

\section{Light measurements}

Spherical irradiance measurements were made using a diver-held Sea-bird 19 CTD (Sea-Bird Electronics, Inc. Bellevue, WA) with an attached spherical quantum sensor (LICOR Inc., Lincoln, NE). Readings were taken only on non-overcast days at approximately the same time each day, and measurements were converted to percent surface irradiance by dividing the irradiance at depth by that just above the surface and multiplying by 100 . Light readings in the experimental plots were averaged from readings of at least three separate days for the analysis. To approximate the available light to the ventral surface, $3 / 4$ of the spherical sensor was covered with black tape and light measurements were taken with the sensor held upside down $2 \mathrm{~cm}$ from the bottom (average distance between Bossiella fronds and the underlying substrate was $20 \mathrm{~mm} \pm 2$ $\mathrm{SE}, \mathrm{n}=20$ ).

\section{Natural pigment variation}

Natural differences in phycoerythrin concentration between depth and plant surface (dorsal and ventral) were examined from 40 plants, 20 from $18 \mathrm{~m}$ and 20 from $27 \mathrm{~m}$ on an offshore vertical wall (site described in Watanabe and Harrold 1991). 
Differences in phycoerythrin fluorescence (see below for methods) were tested using a two-factor Model I ANOVA. Because variances were heterogeneous, data were transformed using $\log (1+x)$ which resulted in a non-significant Cochran's Test (Winer 1971). All statistics were done using Systat v. 5.04 software. From these plants, a mean precision curve was calculated by randomly recalculating precision $(n=3)$ to estimate the number of plants to use in the field experiments.

Field experiments

To investigate the general hypothesis that pigment concentrations do not change over time if light intensities varied, plants were placed in shaded and unshaded conditions at $16 \mathrm{~m}$ and unshaded conditions at $7 \mathrm{~m}$ on two small $\left(100 \mathrm{~m}^{2}\right)$ reefs. The reefs were separated by about $200 \mathrm{~m}$, and the experiment was done from May-July 1993. Although Bossiella has been found to be most abundant at $16 \mathrm{~m}$ depth in Stillwater Cove (Konar and Foster 1992), the $7 \mathrm{~m}$ reef was selected because of its increased natural irradiance (Table 1). To reduce variance in irradiance during the experiment, all macroalgal canopies around the sites were removed two weeks prior to the start and maintained throughout the duration of field experiments.

To vary light at the $16 \mathrm{~m}$ site, unshaded and shaded platforms were made from concrete blocks covered with vexar screen. Plants on unshaded blocks were used as transplant controls, and plants on shaded blocks (PVC frames cemented into blocks and covered with black polyurethane sheets) were exposed to reduce light. For these experiments, separate dorsal (normally-oriented) and upturned ventral fronds were attached to ten blocks for each treatment. All plants for experiments were collected randomly from nearby reefs of the same depth and cleared-canopy light regime. A single frond was selected haphazardly from each plant and attached to the blocks with cable ties. 
To test how the pigment levels in the dorsal surface of Bossiella change over time at different light intensities, plants were placed at the two different light levels (shaded and unshaded) at $16 \mathrm{~m}$. Ten plants from each treatment were collected after five weeks, and ten plants were collected again after 10 weeks for analysis. Unmanipulated plants (hereafter called natural plants) were collected randomly from the same $16 \mathrm{~m}$ bench after both time periods for comparison.

To test how the pigment levels on the ventral surface change over time and with increased light intensity, upturned ventral fronds were also placed at the two different light levels at $16 \mathrm{~m}$. Natural plants were collected randomly from the same $16 \mathrm{~m}$ reef to compare the normally-occurring ventral surface pigmentation to the upturned ventral surfaces under unshaded and shaded conditions.

To test how pigment concentrations in the plant surfaces change between plants acclimated to shaded and unshaded conditions at $16 \mathrm{~m}$ and plants placed in unshaded conditions at increased irradiance, plants from $16 \mathrm{~m}$ were transferred to $7 \mathrm{~m}$. Plants were acclimated to unshaded and shaded light levels at the $16 \mathrm{~m}$ bench for five weeks and then ten plants from each treatment were moved to the $7 \mathrm{~m}$ site. The plants at $7 \mathrm{~m}$ were collected after five weeks and these plants were compared to plants growing under the unshaded, shaded and natural conditions at $16 \mathrm{~m}$. As in the previously described experiments, both dorsal and upturned-ventral fronds were examined.

Differences in pigments among various treatments were examined with an ANOVA. Variances were heterogeneous, and the data were transformed using $\log (1+x)$ which resulted in a non-significant Cochran's Test. A two-way fixed ANOVA was used to examine the differences in phycoerythrin and chlorophyll $a$ over time (5 and 10 weeks) and light intensity (natural, unshaded on blocks, and shaded on 
blocks). Dorsal and ventral surfaces were analyzed separately for pigment concentration. Eight post-hoc comparisons were done on the results for all four sets of analyses (phycoerythrin dorsal, phycoerythrin ventral, chlorophyll a dorsal, chlorophyll $a$ ventral) using Bartlett's multiple comparison adjusted for the number of comparisons of interest. Power of non-significant interactions on multiple comparisons was examined (Zar 1984). A separate one-way fixed ANOVA on transformed $(\log (1+x))$ data for both dorsal and upturned ventral surfaces was used to analyze the effects of light treatments (natural, unshaded on blocks at $16 \mathrm{~m}$, shaded on blocks at 16 $\mathrm{m}$, shallow plants $(7 \mathrm{~m})$ transferred from unshaded treatments, and shallow plants $(7 \mathrm{~m})$ transferred from shaded treatments) on plants grown over a five week period.

\section{Reproductive Structures}

Plants from the experimental manipulations were examined for reproductive condition. The dorsal surface and ventral surfaces on all plants were categorized as being reproductive, post reproductive, or non-reproductive according to conceptacle development. A reproductive plant was one with conceptacles that contained spores as observed under a dissecting microscope at 10x. Post-reproductive plants had degraded conceptacles and no spores. No conceptacles were found on non-reproductive plants.

\section{Collection, Preparation and Pigment Extraction}

At the termination of each experiment, fronds were collected and placed in opaque film canisters and kept on ice until frozen in the laboratory at $-4^{0} \mathrm{C}$. Plant tissue was separated into dorsal and ventral surfaces by removing the undesired surface using a circular Polisher Grinder (Buehler Ecomet III, 600 grit paper) and analyzing the opposite surface. Because Bossiella has apical growth and the growing edge is often white, the first geniculum of the frond was not used. Dorsal and ventral surfaces were always from separate plants. The area of the plant fragment surface was measured to 
the nearest $\mathrm{mm}^{2}$ using Image $\circledast$ software (v. 1.37) at $1 \mathrm{x}$ power. Separate plant fragments were used from same frond when both chlorophyll $a$ and phycoerythrin were extracted.

Two different extracting solutions for phycoerythrin were used, 1) a lysozyme solution (Stewart and Farmer 1984) and 2) potassium phosphate buffer. Phycoerythrin in Bossiella did not extract with the lysozyme solution. Various extraction solutions have been used (Appendix I), so several experiments were run using monocultures of Porphyridium purpureum extracted at molarities ranging from $0.01-0.75$ and $\mathrm{pH}$ ranging from 6.5-7.5. The greatest fluorescence response was in a $0.75 \mathrm{M} \mathrm{K}_{2} \mathrm{POH}_{4}$ solution at $\mathrm{pH} 6.8$ as used by Glazer (1988) and the solution was used to extract phycoerythrin. Chlorophyll $a$ was extracted in a $90 \%$ acetone solution (Jefferey and Humphrey 1975).

Fragments were placed in $5 \mathrm{ml}$ of solution and refrigerated for 12 hours. The fragments were homogenized with a Teflon-coated drill bit for approximately 10-15 seconds or until all calcium carbonate fragments were broken. The solutions were centrifuged for 5 minutes at $3000 \mathrm{rpm}$, and an aliquot of $1.5 \mathrm{ml}$ was micro centrifuged at $14,000 \mathrm{rpm}$ to remove finer particulates. Fluorescence was measured using a Model $16810.22 \mathrm{Spec} \circledast$ Fluorometer. Phycoerythrin fluorescence was measured by exciting the solution at $495 \mathrm{~nm}$ and reading the emission scan at $572 \mathrm{~nm}$. Chlorophyll $a$ fluorescence was measured by exciting the solution at $430 \mathrm{~nm}$ and reading the emission scan at $670 \mathrm{~nm}$. Measurements are reported in relative fluorescence units and normalized for the area analyzed (f. u. $/ \mathrm{mm}^{2}$ ). 


\section{Results}

\section{Light measurements}

The irradiance on the vertical wall when natural plants were collected was measured under a partial canopy of Macrocystis pyrifera and declined with depth as expected (Table 1). Percent of surface irradiance on the cleared $16 \mathrm{~m}$ bench with no canopy was $4.02 \%$ and $0.40 \%$ under the shaded blocks. At the $7 \mathrm{~m}$ cleared bench, the irradiance was $14.2 \%$.

Light readings were taken throughout the study for relative irradiance comparisons at a variety of locations with and without Bossiella in Stillwater Cove. In an area at $12 \mathrm{~m}$ where both Macrocystis pyrifera and Pterygophora californica were cleared, the irradiance was $6.4 \%$. In the same area under $P$. californica canopy, the irradiance was reduced to $1.7 \%$. In a tunnel at the $7 \mathrm{~m}$ site where Bossiella was not present, the irradiance was $0.32 \%$.

Irradiance measured with the partially covered upside down sphere decreased only slightly with depth (Table 1) and was similar on a cleared horizontal bench and on the vertical wall. The light available to the undersurface of the plant frond was slightly lower than that under the shaded blocks (Table 1).

\section{Natural Collections}

Dorsal surfaces contained significantly more phycoerythrin than ventral surfaces at both the shallow and deep site (Table 2). Slightly more phycoerythrin was measured on the dorsal surface of shallow $(18 \mathrm{~m})$ than deep $(27 \mathrm{~m})$ plants (Table 2$)$, but the differences were not significant and power was only $30 \%$.

Cumulative precision $(\mathrm{SE} / \mathrm{X})$ was highest in 10-12 samples in all four treatments (Fig. 1). Variance became smaller at ten samples. A sample size of ten was therefore 
chosen for the field experiments based on the amount of sample processing time and highest precision available.

\section{Field Experiments}

Main effects were analyzed by treatment level because was a significant interaction between time and light level in the dorsal surfaces of Bossiella (Table 3A). Phycoerythrin was significantly higher in natural vs. shaded dorsal surfaces, but not in natural dorsal vs. unshaded dorsal plants after five weeks at $16 \mathrm{~m}$ (Fig. 2A). After ten weeks phycoerythrin fluorescence increased in the shaded treatment (Fig. 2A) and was significantly different from the natural and unshaded treatments. Natural dorsal surfaces did not differ significantly from unshaded surfaces at this time (Fig. 2A). Power never exceeded $40 \%$.

The main effects were also analyzed by treatment level because there was a significant interaction between time and light in the ventral surfaces of Bossiella (Table 3B). Phycoerythrin fluorescence was not significantly different between natural and upturned surfaces in either shaded and unshaded plants after five weeks (Table 2B). The power of these multiple comparisons was $20 \%$. Phycoerythrin decreased in the natural ventral surfaces and increased in upturned ventral surfaces in the shaded treatments after ten weeks (Fig. 2B). Phycoerythrin in both upturned ventral surfaces was significantly higher than the natural ventral surface after ten weeks.

Five weeks after plants were transferred to $7 \mathrm{~m}$, dorsal phycoerythrin levels were significantly different among several of the five varying light treatments (shaded plants $(16 \mathrm{~m})$, unshaded plants $(16 \mathrm{~m})$, natural plants $(16 \mathrm{~m})$, shallow plants $(7 \mathrm{~m})$ transferred from unshaded treatments, shallow plants $(7 \mathrm{~m})$ transferred from shaded treatments) (Table 4A). Neither plants from previously unshaded nor shaded blocks (16 $\mathrm{m})$ differed from each other at $14 \%$ irradiance $(7 \mathrm{~m})$. However, the dorsal surface of 
plants transferred from shaded blocks to $14 \%$ irradiance had more phycoerythrin than the shaded plants grown at $0.4 \%$ irradiance (Table $4 \mathrm{~A}$ ). There were no significant differences among light treatments for upturned ventral surfaces (upturned ventral shaded plants $(16 \mathrm{~m})$, upturned ventral unshaded plants $(16 \mathrm{~m})$, natural plants $(16 \mathrm{~m})$, upturned ventral shallow plants $(7 \mathrm{~m})$ transferred from unshaded treatments, upturned ventral shallow plants $(7 \mathrm{~m})$ transferred from shaded treatments) (Table 4B).

Chlorophyll $a$ levels in the dorsal surfaces were significantly different between light levels but not time (Table 5A). Chlorophyll $a$ did not differ between treatments after five weeks, but decreased significantly between five and ten weeks in natural plants (Fig. 3A). After five weeks, chlorophyll a in the shaded treatments increased with time but not significantly. After ten weeks, the chlorophyll $a$ in natural dorsal surfaces was significantly lower than in both shaded and unshaded blocks. Chlorophyll $a$ from shaded plants $(0.4 \%$ irradiance) was three times greater than unshaded plants (4.0\% irradiance) after ten weeks.

Time and light had a significant interactive effect on chlorophyll $a$ measured on the ventral surface of Bossiella (Table 5B). Like ventral phycoerythrin fluorescence, chlorophyll a did not differ significantly among treatments after five weeks (Fig. 3B) or in the natural ventral surfaces after ten weeks. The upturned ventral surfaces, however, were higher in chlorophyll $a$ in both unshaded and shaded treatments on blocks, and chlorophyll a was significantly higher in the shaded treatment compared to the unshaded treatment after ten weeks.

Significant differences in chlorophyll $a$ levels on the dorsal surfaces occurred among the five different light treatments (treatments same as for phycoerythrin) after five weeks (Table 6A). Chlorophyll $a$ levels in the dorsal surfaces in natural $(16 \mathrm{~m})$, unshaded, shaded $(16 \mathrm{~m})$ and plants $(7 \mathrm{~m})$ transferred from shaded treatments had more 
chlorophyll a than plants $(7 \mathrm{~m})$ transferred from shaded blocks. Plants $(7 \mathrm{~m})$ transferred from the shaded treatment had more chlorophyll $a$ than shallow plants transferred from the unshaded treatment. A one-way Model I ANOVA suggested significant differences among chlorophyll $a$ measurements made on the ventral surface. However, no significant treatment differences were found using a multiple comparisons test (Table 6B). The plants in all increased irradiance treatments remained dark purple and never appeared bleached.

Phycoerythrin to chlorophyll $a$ ratios changed over time and with varying light regimes (Fig. 4). After five weeks, phycoerythrin to chlorophyll $a$ ratios were lower in the shaded treatments. As light increased, there was a trend of more chlorophyll $a$ than phycoerythrin. Shaded treatments after five weeks had lower ratios (dorsal surface = 0.41 ; upturned ventral surface $=0.61$ ) than the treatments with higher light levels (control and unshaded). There was more phycoerythrin than chlorophyll $a$ in all increased light levels (14\%) of the shallow treatments. Both chlorophyll $a$ and phycoerythrin increased after 10 weeks, but the ratio of phycoerythrin to chlorophyll $a$ was less in the shaded treatments ( 0.84 dorsal, 0.90 upturned ventral) compared to the unshaded treatments ( 0.55 dorsal, 0.76 upturned ventral). The shaded plants in the ten week treatments generally contained more phycoerythrin, but the upturned ventral surfaces had higher ratios than the normally oriented dorsal surface.

\section{Reproductive development}

Conceptacle development ranged from $30 \%-89 \%$ over all treatments after the five weeks (Table 7). Only one out of 160 plants in the field was found to have conceptacles on the ventral surface. After five weeks, the dorsal surface that previously had conceptacles still had reproductive conceptacles even though four of the five treatments were now upside down. The overturned dorsal surfaces contained slightly 
more post-reproductive conceptacles (11\%-56\%). The newly upturned ventral surface of several plants became reproductive, in both shaded and plants moved to shallow water $(7 \mathrm{~m})$ from shaded blocks after five weeks. Dorsal surfaces varied in their reproductive status after ten weeks, in both the normal and overturned surfaces. Two additional plants from the upturned ventral surface treatments became reproductive after ten weeks. 


\section{Discussion}

In the aquatic environment, as depth decreases, light intensity as well as spectral distribution (Kirk 1983) decreases. Ramus and van der Meer (1983) found that intensity was more important than spectral distribution to changes in pigment concentration of Gracilaria tikvahiae (Machlan), and it is generally accepted, based primarily on lab studies, that seaweeds are "intensity" adapters and not "chromatic" adapters (Levy and Gantt, 1988, Beer and Levy 1983, Dring 1981, Ramus 1981, Ramus and van der Meer 1983). By shading plants at $16 \mathrm{~m}$, a low light environment in the field was created without changing the spectral distribution available to the plants. Thus, only the effects of light intensity and thallus orientation on the two major photosynthetic pigments were considered.

Concentration of pigments from natural plants collected from a vertical wall did not differ significantly with depth, although there was a difference between concentration in plant surfaces (dorsal and ventral) at each depth. The dorsal surfaces, which are exposed to more light, contained more phycoerythrin. It is difficult to find habitats where changes in light intensity with depth are not confounded by other factors. Overstory algal canopies present a particular problem. The distribution of Bossiella is fairly broad, ranging from $10 \mathrm{~m}$ to over $40 \mathrm{~m}$ (pers. obs.). Testing for pigment differences over this range can be difficult because of environmental heterogeneity with depth. The Macrocystis pyrifera canopy alone can vary temporally as well as spatially (Reed and Foster 1984). Vertical walls are thus an ideal habitat to examine differences in pigment content over a depth range. The only in situ study done on the relationship between light and pigments in benthic macroalgae was by Ramus $e t$ al. (1976) who investigated pigment concentrations, as a function of depth by suspending Ulva lactuca, Codium fragile, Chondrus crispus, and Porphrya umbilicalis 
on lines in the water column. This method may not be appropriate for Bossiella. In Stillwater Cove, CA, Bossiella has not been seen growing naturally on buoy lines within its depth range, therefore suspending Bossiella on ropes in the field to achieve depth gradients may introduce artifacts to the experiment. It is probable that light intensities on the vertical wall (discussed below) were not different enough to distinguish natural changes in phycoerythrin with depth. The combination of low power and little relative change in precision from 10 to 20 samples indicated that the variability in pigment content between depths was very low. However the difference in phycoerythrin between dorsal and ventral surfaces was large enough to distinguish it from the variability in the population.

Differences in light levels between the natural collections were less than differences in levels between the experimental treatments in the rest of the study. Subsurface irradiance at $18 \mathrm{~m}$ was twice that at $27 \mathrm{~m}$. In the experimental light treatments, light at $7 \mathrm{~m}$ was 3.5 times higher than at $16 \mathrm{~m}$, and the irradiance on $16 \mathrm{~m}$ without canopy was 10 times greater than the shaded blocks. Irradiance at the $7 \mathrm{~m}$ site was 35 times higher than the shaded blocks at $16 \mathrm{~m}$ (Table 1). The $16 \mathrm{~m}$ shaded treatments were only 2.7 times higher than light available to the naturally oriented ventral surface. Ramus et al. (1976) found significantly more phycoerythrin relative to chlorophyll $a$ with 10 times less irradiance between one and 10 meters in a coastal bay. One explanation for my results may be that Bossiella has a minimum light requirement above which (i.e. the shaded treatments) irradiance needs to be radically different to produce changes in pigment concentration.

The natural ventral surface was less pigmented than both upturned and normally-oriented plants under the shaded treatment, further suggesting a minimum light requirement for pigment production. Bossiella is the only subtidal coralline in this 
area that demonstrates this pigment pattern as well as the dorsi-ventral orientation (Roberts, pers obs.). The light levels in the shaded treatment were not as low as light naturally available to the ventral surface. The increase in both chlorophyll $a$ and phycoerythrin after ten weeks in the shaded treatments and in the upturned ventral surfaces suggest that Bossiella requires a minimum light level for pigment production but still increases concentrations in response to low light levels that are above the light available to the ventral surface. Leukart and Luning (1994) found that the minimum white light levels necessary for red algal growth were on the order of 0.2 to $1.0 \mu \mathrm{mol}$ $\mathrm{m}^{-2} \mathrm{~s}^{-1}$. In this study, the lowest irradiance measured under the shaded block treatment was $1.2 \mu \mathrm{mol} \mathrm{m} \mathrm{m}^{-2} \mathrm{~s}^{-1}$. This irradiance was still higher than light available to the ventral surface $\left(x=0.15 \mu \mathrm{mol} \mathrm{m}^{-2} \mathrm{~s}^{-1}\right.$ ) suggesting that Bossiella can thus photoacclimate to varying light environments. Few studies have addressed the minimum light requirements for lower limits of red algae. The deep growing coralline alga $(290 \mathrm{~m})$ Lithophyllum sp. occurred where irradiance was $0.24 \mu \mathrm{mol} \mathrm{m}^{-2} \mathrm{~s}^{-1}$ (Littler et al. 1991). Leukart and Luning (1994) reported the lower light limits for growth of Chrondras crispus to be at least $0.5 \mu \mathrm{mol} \mathrm{m}^{-2} \mathrm{~s}^{-1}$ in the lab. Perhaps for a plant that has the ability to maintain a dorsi-ventral orientation, there is no need to have more pigment on the ventral surface. In a horizontally-oriented plant like Bossiella, less pigmentation on the ventral surface may be a way to minimize energy costs associated with pigment production.

The natural plants collected for controls in the experimental treatments less chlorophyll $a$ and phycoerythrin in the naturally-oriented ventral surface. Several other studies of plants grown in very low light or dark conditions contained varying results in amount of chlorophyll $a$ and phycoerythrin. In a study of Maripelta rotata (Dawson) grown in the dark, no evidence of chlorophyll $a$ was reported, however, 
phycobiliproteins were clearly present (Bowen 1971). Luning and Schmitz (1988) found that Delessaria sanguinea (Hudson) Lamouroux grown in the dark had phycobiliproteins, which were probably phycoerythrin, and showed no evidence of chlorophyll $a$. The brown alga, Laminaria hyperborea (Gunnerus) Foslie grew blades in continued darkness while absorption spectra showed the alga to contain chlorophyll $a$ and accessory fucoxanthins (Luning 1986). In Bossiella, the naturally-oriented surfaces vary in the amount of chlorophyll a found in the ventral surface. This could be due to natural variability between sampling times, however the assumption that the plant's orientation does not change makes this idea unlikely. Some other factor may be controlling the pigment variation in the naturally-oriented ventral surface.

The significant increase in concentrations of both chlorophyll $a$ and phycoerythrin in the upturned ventral surfaces of experimental plants after ten weeks at $16 \mathrm{~m}$ suggest that thallus orientation, increased light, and time affect pigment patterns in Bossiella. After the first five weeks, both pigments in the upturned ventral surface remained relatively unchanged. After ten weeks, however, pigments in the upturned ventral surfaces increased significantly, but the natural ventral surfaces did not. In this study, pigment changes occur slowly. Porphyridium purpureum grown under 10-180 $\mu$ $\mathrm{E} \mathrm{m}^{-2} \mathrm{~s}^{-1}$ required several days or weeks for pigment changes to occur (Levy and Gantt 1988). Ramus et al. (1976) recorded changes in chlorophyll $a$ and $b$ in Ulva lactuca, Codium fragile, and chlorophyll $a$ and phycoerythrin in Chondrus crispus, and Porphrya umbilicalis after one week. Waaland et al. (1974) found increased phycoerythrin in Griffithsia pacifica after three months when plants were grown at four different light intensities. Algarra and Neill (1990) found pigment responses to different light intensities after five hours in Corallina elongata.

The results of the $7 \mathrm{~m}$ experiments may be influenced by exposure time. These 
plants were exposed to increased irradiance (14\%) for five weeks so may still have been acclimating from the previous treatments at $16 \mathrm{~m}$. The $16 \mathrm{~m}$ bench was cleared of overstory canopies two weeks prior to the start of the experiment. This means that the natural plants were not true controls for the surrounding kelp forest at $16 \mathrm{~m}$, but really a treatment control for fronds of Bossiella placed on blocks. If Bossiella takes at least five weeks to acclimate to a new light regime then the results after five weeks may have been a product of both acclimation to an increased irradiance from canopy clearings and the experimental treatment. Moreover chlorophyll $a$ variation in natural plants between five and ten weeks may have been a response, in part, to the initial canopy clearings.

As expected, the ratios of phycoerythrin to chlorophyll $a$ increased in the shaded treatments after ten weeks, but this also occurred at the shallow sites after five weeks. This was suprising as the current literature suggests that chlorophyll $a$ will increase with increased light. Ramus et al. (1976) showed that plants collected from low light intertidal habitats had overall increases in both accessory pigments and chlorophyll $a$, but not in the ratios of accessory pigments to chlorophyll $a$. Waaland $e t$ al. (1974) also reported a lower phycoerythrin to chlorophyll $a$ ratio at higher light intensity. In Bossiella both pigments increased in high light, but there appeared to be more chlorophyll $a$ than in the shaded treatments. Phycoerythrin increased relative to chlorophyll $a$ between five and ten weeks in the natural plants from the field experiments, which may have been an acclimation to the initial clearings for the experimental treatment. In another study, at approximately the same time, several species of geniculate corallines at $10 \mathrm{~m}$ became bleached after the surface canopy was cleared (Roberts, pers. obs). After approximately three to four weeks the same plants 
became pigmented again indicating coralline concentrations may respond to initial increased light but have the ability to produce phycoerythrin under the same conditions.

Apical growth in Bossiella results in new cells being added only to the distal end of the last geniculum (Johanson 1981). Pigment changes can thus occur in the absence of cell division. In studies of structural adaptations of Corallina elongata, Ellis \& Soland, Algarra and Neill (1987) found a high degree of plasticity, and that sun and shade adapted plants were convertible morphotypes. Growth in robust species of corallines, like Bossiella, is slower than more delicate species of corallines such as Corallina officianalis (Colthart and Johansen 1970). Growth rates in Bossiella ranged from 0.3 to $0.6 \mathrm{~mm}^{-1}$ month in the spring (Konar and Foster 1992). This may result in slower pigment changes than have been found in other photoacclimation studies of the fleshy red algae. In a robust, long-lived perennial plant like Bossiella, irradiance changes over less than five weeks do not appear to be detrimental to plant survival.

The general response of micro and macroalgae to reduced photon flux densities is to increase cellular pigment content and/or change pigment composition (Richardson et al. 1983). Ecological results suggest that in nature, photoacclimation plays an important role in buffering the photosynthetic performance in the face of variations in irradiance (Falkowski and LaRoche 1991). As pigments in cells increase to compensate for the reduction in irradiance, the absorption efficiency that a plant can absorb light may decrease. However relatively little is known about the level at which this occurs, i.e. are there changes in the number and/ or size of the photosystems or of the antennae complexes (Gantt 1990). The degree to which this occurs may vary within species. The logical next step would be to investigate growth rate and photosynthetic responses of Bossiella to these different high and low light intensities. 
Limited reproductive development was observed on upturned ventral surfaces. Light attributes that have been directly linked to algal reproduction are photoperiod (Luning 1980, 1981b) and total daily irradiance (Luning and Neushul 1978). This study was done in the late spring through early summer, with the summer solstice in the middle of the experiment, so photoperiods were similar during both time periods. Konar (1993) found Bossiella to be reproductive throughout much of the year, but conceptacle development was significantly higher in the spring and fall. Conceptacles were never found on the ventral surface, and the most reproductive plants were at $15 \mathrm{~m}$ (Konar 1993). I found that upturned shaded plants became reproductive. Jones and Woelkerling (1983) in laboratory studies on geniculate coralline, Fossiella cruciata Bressen, found that conceptacle production required $65 \mathrm{~d}$ at photon flux densities of 3.0-6.5 $\mu \mathrm{mol} \mathrm{m}-2 \mathrm{~s}^{-1}$, and development did not occur after $33 \mathrm{~d}$ at $12-25 \mu \mathrm{mol} \mathrm{m}^{-2} \mathrm{~s}^{-1}$. Rates of conceptacle production in $F$. cruciata may be higher than in more robust species like Bossiella (Jones and Woelkerling 1983, Johanson 1981). A true test of whether light or some other factor associated with orientation induces reproductive development would be to suspend the frond and initiate a light source under the plant.

In conclusion, Bossiella californica ssp. schmittii has the ability to photoacclimate in the field, and conceptacle development may be inhibited by low light. Chlorophyll $a$ and phycoerythrin increased in the dorsal portion of the thallus after ten weeks in reduced light environments. Chlorophyll $a$ and phycoerythrin increased in the upturned ventral thallus with increased light after five weeks. Phycoerythrin increased in the dorsal surface after ten weeks when plants were shaded. Several plants developed conceptacles on the ventral surface when they were overturned. 


\section{Literature cited}

Abbott, I. A. \& Hollenberg, G. J. 1976. The Marine Algae of California. Stanford Univ. Press, Stanford, CA, 827 pp.

Algarra, P. \& Niell, F. X. 1987. Structural adaptations to light reception in two morphotypes of Corallina elongata Ellis et Soland. P.S.Z.N. I: Mar. Ecol. 8:25361 .

Algarra, P. \& Niell, F. X. 1990. Short term response of Corallina elongata Ellis et Soland to light intensity. Aquat. Bot. 36:127-38.

Algarra, P., de la Vino, G. \& Niell, F. X. 1991. Effects of light quality and irradiance level interactions on short-term pigment response of the red alga Corallina elongata. Mar. Ecol. Prog. Ser. 74:27-32.

Beer, S. \& Levy, I. 1983. Effects of photon fluence rate and light spectrum composition on growth, photosynthesis and pigment relationships in Gracileria sp. J. Phycol. 19:516-22.

Bowen, K. Y. 1971. The growth and development of the deep growing red alga, Maripelta rotata (Daws.)Daws. Phd. Dissertation, Univ. of CA, San Diego, 220 pp.

Colthart, B. J. \& Johansen, H. W. 1973. Growth rates of Corallina officianalis (Rhodophyta) at different temperatures. Mar. Biol. 18:46-9.

DeBoer, J. A. \& Ryther, J. H. 1978. Potential yield from a waste recycling algal mariculture system. In Krauss R. [ed] The Marine Plant Biomass of the Pacific Northwest Coast. Oregon State Univ. Press, Corvalis, 231-49.

Dring, M. J. 1981. Chromatic adaptation of photosynthesis in benthic marine algae: An examination of its ecological significance using a theoretical model. Limnol. Oceanogr. 26:271-84. 
Dring, M. J. 1986. Pigment composition and photosynthetic action spectra of sporophytes in Laminaria (Phaeophyta) grown in different light qualities and irradiances. British J. Phycol. 21:199-207.

Duysens, L. N. M. 1951. Transer of light energy within the pigment system present in photosynthesizing cells. Nature 168:548-50.

Falkowski, P.G. \& LaRoche, J. 1991. Acclimation to spectral iradiance in algae. J. Phycol. 27:8-14.

Foster, M. S. \& Schiel, D. R. 1985. The ecology of giant kelp forests: a community profile. U.S. Fish. Wildl. Serv. Biol. Rep. 85(7.2) 152 pp.

Fujita, Y., Qhki, K., \& Murakami, A. 1985. Chromatic regulation of photosystem composition in the photosynthetic system of red and blue-green algae. Plant Cell Physiol. 26:1541-8.

Gantt, E. 1981. Phycobilisomes. Annu. Rev. Plant Physiol. 32:327-47.

Gantt, E. 1990. Pigmentation and Acclimation. [eds.] Cole, K. and R. Sheath. Biology of the Red Algae. Cambridge Univ. Press, Cambridge. 203-19.

Glazer, A. N. 1984. Phycobilisome. A macromolecular process in energy transfer. Biochim. Biophys. Acta. 768:28-51.

Glazer, A. N. 1985. Light harvesting by phycobilisomes. Annu. Rev. Biophys. Chem. 14:47-77.

Glazer, A. N. 1988. Phycobilisomes. Methods in Enzymology. 167:305-14.

Haxo, F. T. \& Blinks, L. R. 1950. Photosynthesis action spectra of marine algae. J. Gen. Physiol. 33:389-422. 
Jeffery, S. W. \& Humphrey, G. F. 1975. New Spectrophotometric Equations for determining Chlorophylls a, b, cl, and $\mathrm{c} 2$ in higher plants, algae, and natural phytoplankton. Biochem. Physiol. Pflanzen (BPP) 167:191-4.

Johansen, H. W. 1981. Coralline algae. A first synthesis. CRC Press Inc., Florida, 239 pp.

Johanson, H. W. 1973. Ontogeny of sexual conceptacles in a species of Bossiella (Corallinaceae). J. Phycol. 9:141-8.

Jones, P. L. \& Woelkerling, W. J. 1983. Some effects of light and temperature on growth and conceptacle production in Fosliella cruciata Bressan (Corallinaceae, Rhodophyta). Phycologia 22:449-52.

Kana, T. M. \& Gilbert, P. M. 1987. Effect of irradiances up to $2000 \mathrm{E} \mathrm{m}-2 \mathrm{~s}-1$ on marine Synechococcus Wh7803-I. Growth, pigmentation, and cell composition. Deep-Sea Res. 34:479-95.

Kirk, J. 1983. Light and Photosynthesis in Aquatic Ecosystems. Cambridge University Press. Cambridge. 399 pp.

Konar, B. 1993. Demography and morphology of the geniculate coralline, Bossiella californica ssp. schmittii (Corallinales, Rhodophyta), in a central California kelp forest. Phycologia 32:284-90.

Konar, B. \& Foster, M. S. 1992. Distribution and recruitment of subtidal geniculate coralline algae. J. Phycol. 28:273-80.

Lapointe, B. E. 1981. The effect of light and nitrogen on growth, pigment content, and biochemical composition of Gracilaria folifera v. angustissima (Giartinales, Rhodophyta) J. Phycol. 17:90-5. 
Lapoint, B. E. \& Ryther, J. H. 1979. The effects of nitrogen and seawater flow rate on the growth and biochemical composition of Gracilaria folifera v. angustissima in mass outdoor cultures. Bot. Mar. 22:529-37.

Larkum, A. W. D. \& Weyrauch, S. K. 1977. Photosynthesis action spectra and light harvesting in Griffithsia monillis (Rhodophyta). Photochem. Photobiol. 25:65-72.

Larkum, A. W. D. \& Barrett, J. 1983. Light-harvesting processes in algae. Adv. Bot. Res. 10:1-219.

Leukart, P. \& Luning, K. 1994. Minimum spectral light requirements and maximum light levels for long term germling growth of several red algae from different water depths and a green alga. Eur. J. Phycol. 29:103-12.

Levy, I. \& Gantt, E. 1988. Light acclimation of Porphyridium purpureum (Rhodophyta): growth, photoacclimation and phycobilisomes. J. Phycol.24:452-8.

Littler, M. M., Littler, D. S. \& Hanisak, M. D. 1991. Deep water rhodolith distribution, productivity, and growth history at sites of formation and subsequent degradation. J. Exp. Mar. Bio. Ecol. 150:163-82.

Littler, M. M., \& Arnold, K. E. 1980. Sources of variability in macroalgal primary productivity: sampling and interpretive problems. Aquatic Bot. 8:141-56.

Lopez-Figueroa, F. \& Niell, F. X. 1990. Effects of light quality on chlorophyll and biliprotein accumulation in seaweeds. Mar. Biol. 104:321-7.

Luning, K. 1981b. Photomorphogenesis of reproduction in marine macroalgae. Ber Deutsch. Bot. Ges. 94:401-17.

Luning, K. 1986. New frond formation in Laminaria hyperborea (Phaeophyta): a photoperiodic response. Br. Phycol. J. 21:269-73. 
Luning, K. 1990. Seaweeds: Their Environment, Biogeography, and Ecophysiology. J. Wiley \& sons, Inc., New York, pp 277-320.

Luning, K., \& M. Neushul. 1978. Light and temperature demands for growth and reproduction of laminarian gametophytes in southern and central California. Mar. Biol. 45:297-309.

Luning, K., \& Schmitz, K. 1988. Dark growth of the red alga Delesseria sanuinea (Ceramiales): lack of chlorophyll, photosynthetic capability and phycobilisomes. Phycologia 27:72-7.

Ohki, K. \& Fujita, Y. 1992. Photoregulation of phycobilisome structure during complementary chromatic adaptation in the marine cyanophyte Phormidium sp. $J$. Phycol. 38:803-8.

Ramus, J. 1981. The capture and transduction of light energy. In Lobban, C. S. \& Wynne, M. J. [Eds.] Biology of Seaweeds. Blackwell, Oxford, pp. 458-92.

Ramus, J. 1983. A physiological test of the theory of complementary chromatic adaptation. II. Brown, Red, and Green seaweeds. J. Phycol. 19:173-8.

Ramus, J., Beale, S. I, Mauzeralli, D. \& Howard, K. L. 1976. Changes in photosynthetic pigment concentration in seaweeds as a function of water depth. Mar Biol. 37:223-9.

Ramus, J., Lemons, F. \& Zimmerman, C. 1977. Adaptation of light-harvesting pigments to downwelling light and the consequent photosynthetic performance of the eulittoral rockweeds Ascophyllum nodosum and Fucus vesiculosus. Mar. Biol. 42:293-303.

Ramus, J. \& van der Meer, J. P. 1983. A physiological test of the theory of complimentary chromatic adaptation. I. Color mutants of a red seaweed. J. Phycol. 19:86-91. 
Reed, D. \& Foster, M. S. 1984. Effects of canopy shading on algal recruitment and growth in a giant kelp forest. Ecology 65:937-48.

Rhee, C. \& Briggs, W. R. 1977. Some responses of Chondrus crispus to light. I. Pigment changes in the natural habitat. Bot. Gaz. 138:123-8.

Richardson, K., Beardall, J. \& Raven, J. A. 1983. Adaptation of unicellular algae to irradiance: an analysis of strategies. New Phytol. 93:157-91.

Rosenberg, G. \& Ramus, J. 1982. Ecological growth strategies in the seaweeds Gracilaria foliifera (Rhodophycea) and Ulva sp. (Chlorophycea): photosynthesis and pigment composition. Mar. Ecol. Prog. Ser. 8:233-41.

Rowen, K. S. 1989. Photosynthetic Pigments of Algae. Cambridge Univ. Press, New York, pp. 166-211.

Saffo, M. B. 1987. New light on seaweeds. Bioscience 37:654-64.

Scheer, H. 1986. Excitation transfer in phycobiliproteins. [eds.] L. A. Staehelin and C. J. Arntzen. in Encyclopedia of Plant Physiology. Vol. 19. Photosynthetic Membranes and Light-Harvesting Systems. 84 pp.

Sivan, A. \& Arad (Malis), S. 1993. Induction and characterization of pigment mutants in the red microalga Porphyridium sp. (Rhodophyceae). Phycologia. 32:68-72.

Spencer, K., Yu, G. M., West, J. A. \& Glazer, A. N. 1981. Phycoerythrin and interfertility patterns in Callithamnion (Rhodophyta) isolates. Br. Phycological J. 16:331-43.

Stewart, D. \& Farmer, F. 1984. Extraction, identification, and quantitation of phycobiliprotein pigments from phototrophic plankton. Limn. Oceanogr. 29:3927. 
Vergara, J. J. \& Niell, F. X. 1993. Effects of nitrate availability and irradiance on internal nitrogen constituents in Corallina elongata (Rhodophyta) J. Phycol. 29:285-93.

Waaland, J. R., Waaland, S. \& Bates, G. 1974. Chloroplast structure and pigment composition in the red alga Griffithsia pacifica: regulation by light intensity. $J$. Phycol. 10:193-9.

Watanabe, J. M. \& Harrold, C. 1991. Destructive grazing by sea urchins Strongylocentrotus spp. in a central califomia kelp forest: potential roles of recruitment, depth and predation. Mar. Ecol. Prog. Ser. 71:125-41.

Wehrmeyer, W. 1988. Phycobilisomes: structure and function. [eds.] A. Coleman, L. Goff, and J. Stein-Taylor. in Algae as Experimental Systems. Alan R. Liss, Inc., New York, pp. 158-72.

Winer, B. J. 1971. Statistical principles in experimental design. McGraw-Hill Book Co., New York, 907 pp.

Yu, M., Glazer, A., Spencer, K. G. \& West, J. A. 1981. Phycoerythrins of the red alga Callithamnion: variation in phycoerythrin and phycourobilin content. Plant Physiol. 68:482-8.

Zar, J. H. 1984. Biostatistical Analysis. Prentice-Hall New Jersey. 620 pp. 
Table 1. Percent surface irradiance at various depths and treatments.

Modification of spherical sensor to approximately $1 / 4$ the sensor

surface and held upside down (see methods) estimated available light to the ventral surface. Treatments marked with * are light levels from experimental benches with surface and subsurface algal canopies removed. Sample size and standard errors ( $n, S E)$ are given where replicate measurements were made.

\begin{tabular}{lccc}
\hline \hline unmodified sensor & $\begin{array}{c}\text { depth } \\
(\mathrm{m})\end{array}$ & $\begin{array}{c}\% \text { PAR } \\
\left(\mu \mathrm{Em}^{2} \mathrm{sec}-1\right)\end{array}$ & $(\mathrm{n}, \pm \mathrm{SE})$ \\
\hline bench (no canopy) $^{*}$ & 7 & 14.20 & $(3,0.57)$ \\
bench (no canopy)* $^{*}$ & 16 & 4.02 & $(4,0.82)$ \\
shaded blocks* $^{*}$ & 16 & 0.40 & $(4,0.10)$ \\
natural collection (shallow) & 18 & 1.09 & \\
natural collection (deep) & 27 & 0.45 & \\
& & & \\
modified sensor & & & \\
bench (no canopy) & 12 & 0.12 & \\
vertical wall & 12 & 0.17 & \\
vertical wall & 14 & 0.11 & \\
vertical wall & 16 & 0.10 & \\
\hline
\end{tabular}


Table 2. Phycoerythrin fluorescence measured from dorsal and ventral surfaces of Bossiella intergenicula collected on a vertical wall, and associated two-factor model I ANOVA [fluorescence units (f. u.) at depth (18 and $27 \mathrm{~m}$ ) vs. surface (dorsal and ventral)]. Power of the ANOVA was $30 \%$.

\begin{tabular}{|c|c|c|c|c|}
\hline $\begin{array}{l}\text { depth } \\
\text { (m) }\end{array}$ & surface & $\begin{array}{c}x \\
\text { (f. } u . \backslash \mathrm{mm}^{2} \text { ) }\end{array}$ & $\begin{array}{c}S E \\
\text { (f. } u . \backslash \mathrm{mm}^{2} \text { ) }\end{array}$ & \\
\hline \multirow[t]{2}{*}{18} & dorsal & 0.72 & 0.03 & \\
\hline & ventral & 0.10 & 0.02 & \\
\hline \multirow[t]{2}{*}{27} & dorsal & 0.63 & 0.04 & \\
\hline & ventral & 0.14 & 0.01 & \\
\hline source & $\mathrm{df}$ & MS & $\mathrm{F}$ & $\mathrm{p}$ \\
\hline depth & 1 & 2.11 & 0.077 & 0.78 \\
\hline surface & 1 & 2.38 & 87.5 & $1.04 * 10^{-4}$ \\
\hline depth $X$ surface & 1 & 6.49 & 2.55 & 0.114 \\
\hline error & 73 & 2.72 & & \\
\hline
\end{tabular}


Table 3.Two-way model I ANOVA for phycoerythrin fluorescence between time ( 5 and 10 weeks) and light levels (natural, unshaded, and shaded plants) in Bossiella.

\begin{tabular}{|c|c|c|c|c|c|}
\hline \multicolumn{6}{|c|}{ Dorsal surface } \\
\hline A & source & df & MS & F & $\mathrm{p}$ \\
\hline & Time & 1 & 0.008 & 2.097 & 0.154 \\
\hline & Light & 2 & 0.008 & 2.217 & 0.120 \\
\hline & $T \times L$ & 2 & 0.061 & 16.855 & $<0.001$ \\
\hline & Error & 49 & 0.004 & & \\
\hline \multicolumn{6}{|c|}{ Ventral surface } \\
\hline B & source & $\mathrm{df}$ & MS & $\mathrm{F}$ & $\mathrm{p}$ \\
\hline & Time & 1 & 0.002 & 0.860 & 0.358 \\
\hline & Light & 2 & 0.008 & 3.767 & 0.030 \\
\hline & $T \times L$ & 2 & 0.025 & 11.181 & $<0.001$ \\
\hline & Error & 50 & 0.002 & & \\
\hline
\end{tabular}


Table 4. One-way model I ANOVA for phycoerythrin fluorescence in Bossiella in five different light treatments. $(\mathrm{S}=$ shaded plants $(16 \mathrm{~m})$; US = unshaded plants $(16 \mathrm{~m}) ; \mathrm{N}=$ natural plants $(16 \mathrm{~m}) ; \mathrm{SUS}=$ shallow plants $(7 \mathrm{~m})$ transferred from unshaded treatments; $S S=$ shallow plants $(7 \mathrm{~m})$ transferred from shaded treatments).

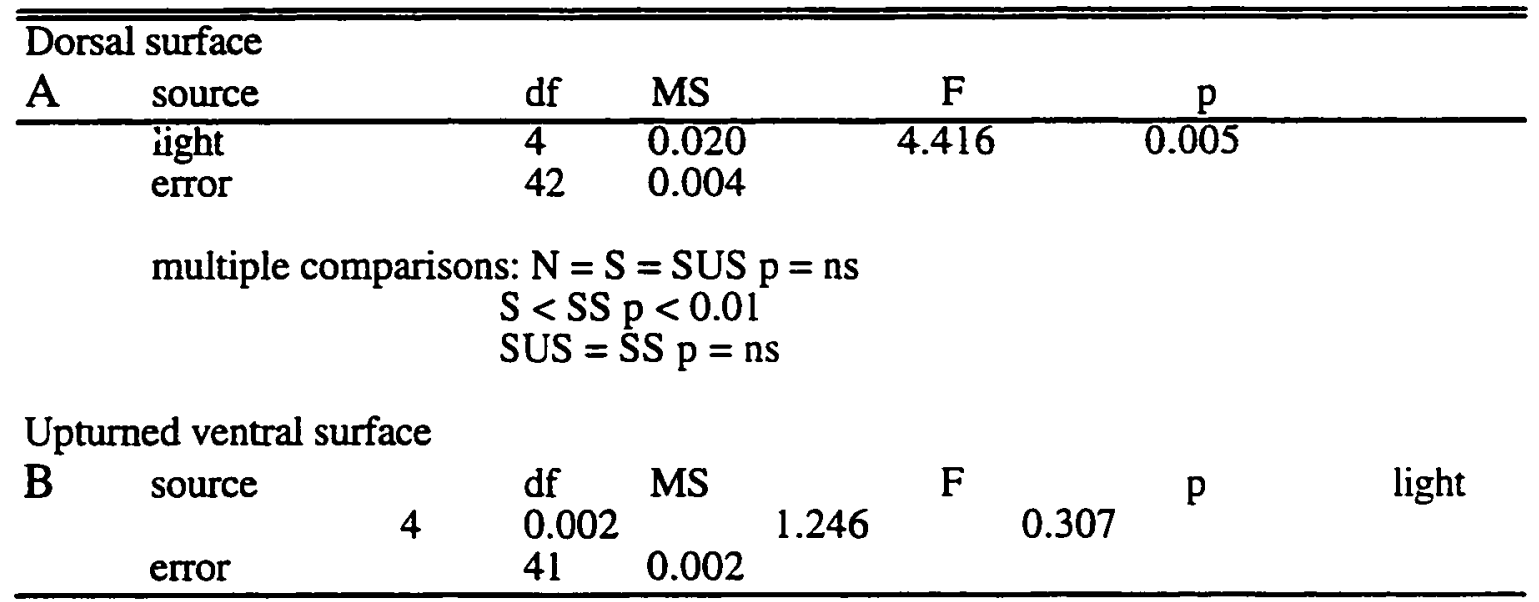


Table 5. Two-way model I ANOVA for chlorophyll a fluorescence between time ( 5 and 10 weeks) and light levels (natural, unshaded, and shaded plants) in Bossiella.

\begin{tabular}{cllllr}
\hline \hline \multicolumn{2}{c}{ Dorsal surface } & & & & \\
$\mathrm{A}$ & source & df & MS & F & p \\
\hline & Time & 1 & 0.000 & 0.175 & 0.678 \\
Light & 2 & 0.046 & 38.587 & $<0.001$ \\
T x L & 2 & 0.039 & 32.651 & $<0.001$ \\
Error & 50 & 0.001 & &
\end{tabular}

Ventral surface

\begin{tabular}{|c|c|c|c|c|c|}
\hline B & source & $\mathrm{df}$ & MS & $\mathrm{F}$ & p - \\
\hline & Time & 1 & 0.004 & 3.258 & 0.077 \\
\hline & Light & 2 & 0.025 & 22.247 & $<0.001$ \\
\hline & $T \times L$ & 2 & 0.006 & 5.726 & 0.006 \\
\hline & Error & 50 & 0.001 & & \\
\hline
\end{tabular}


Table 6. One-way model I ANOVA for chlorophyll a fluorescence in Bossiella in five different light treatments $(\mathrm{S}=$ shaded plants $(16 \mathrm{~m})$; US = unshaded plants $(16 \mathrm{~m})$; $\mathrm{N}=$ natural plants $(16 \mathrm{~m}) ; \mathrm{SUS}=$ shallow plants $(7 \mathrm{~m})$ transferred from unshaded treatments: $\mathrm{SS}=$ shallow plants $(7 \mathrm{~m})$ transferred from shaded treatments).

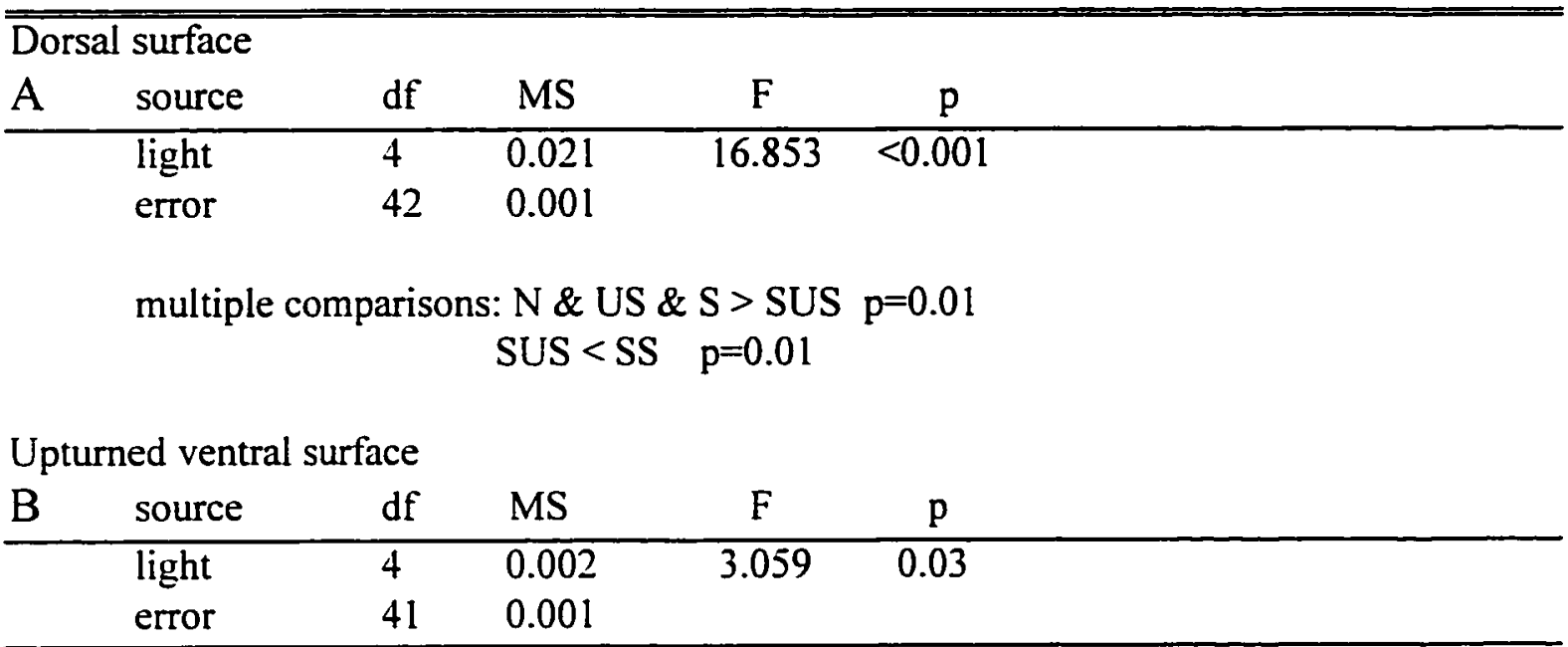




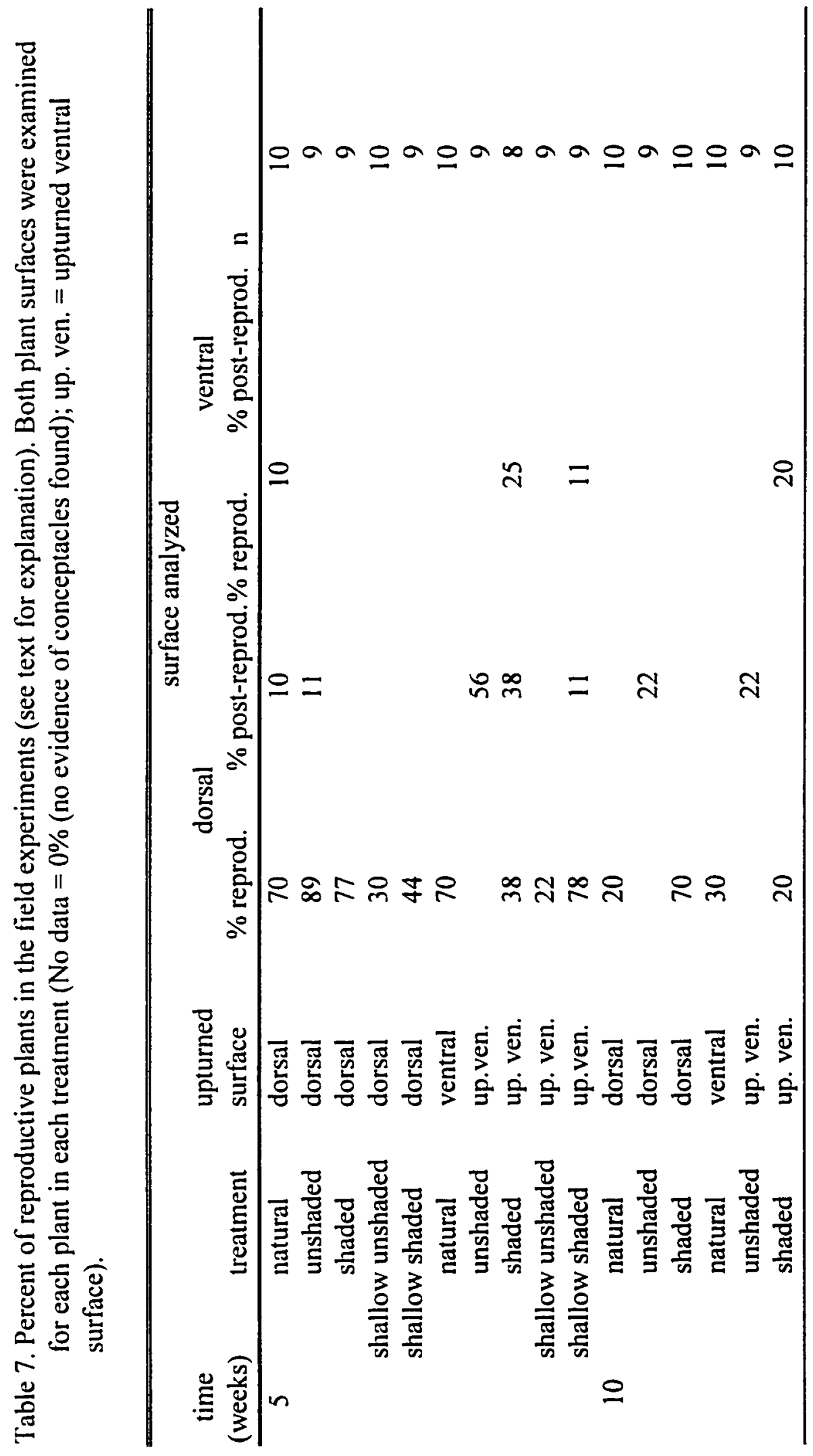




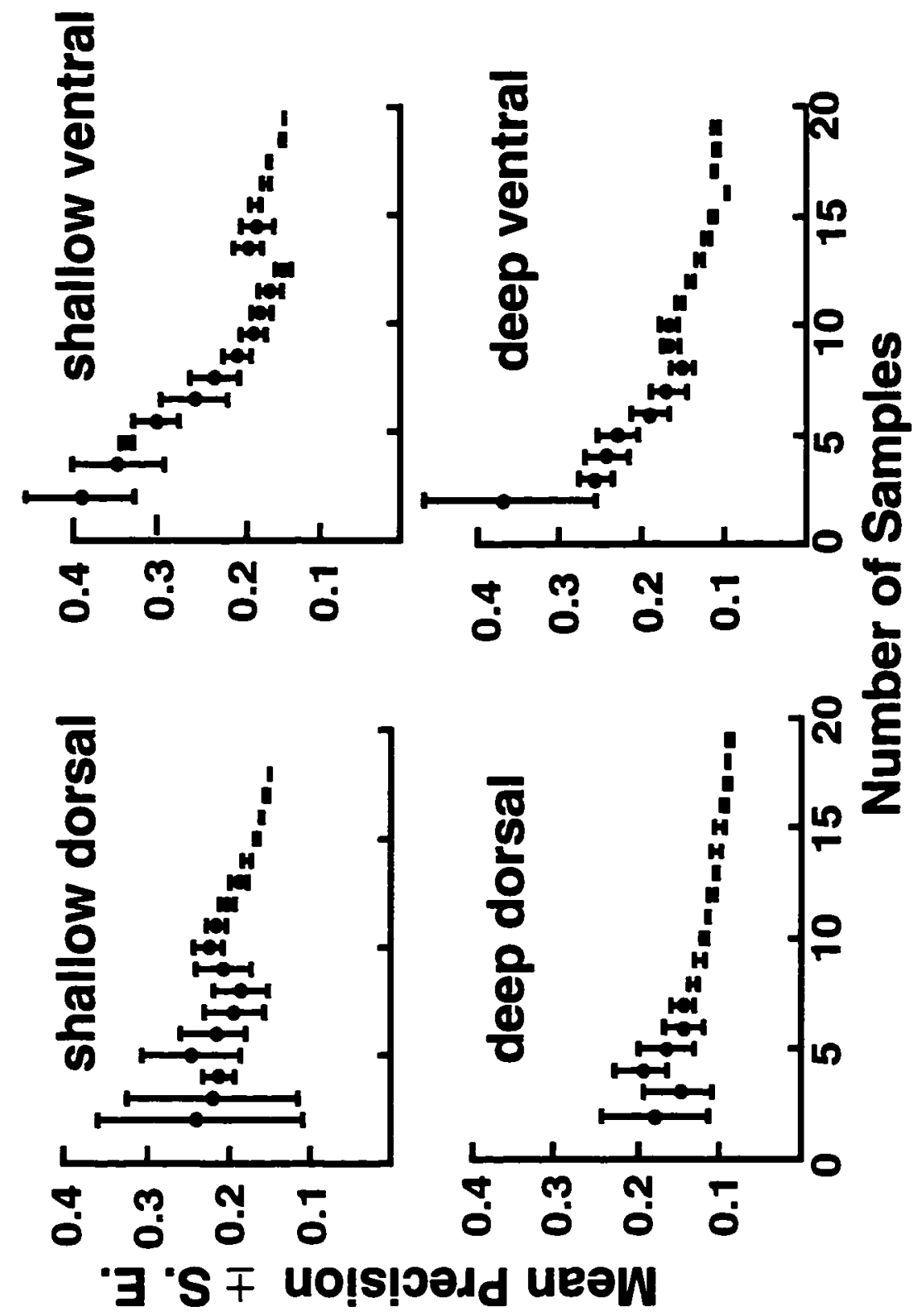




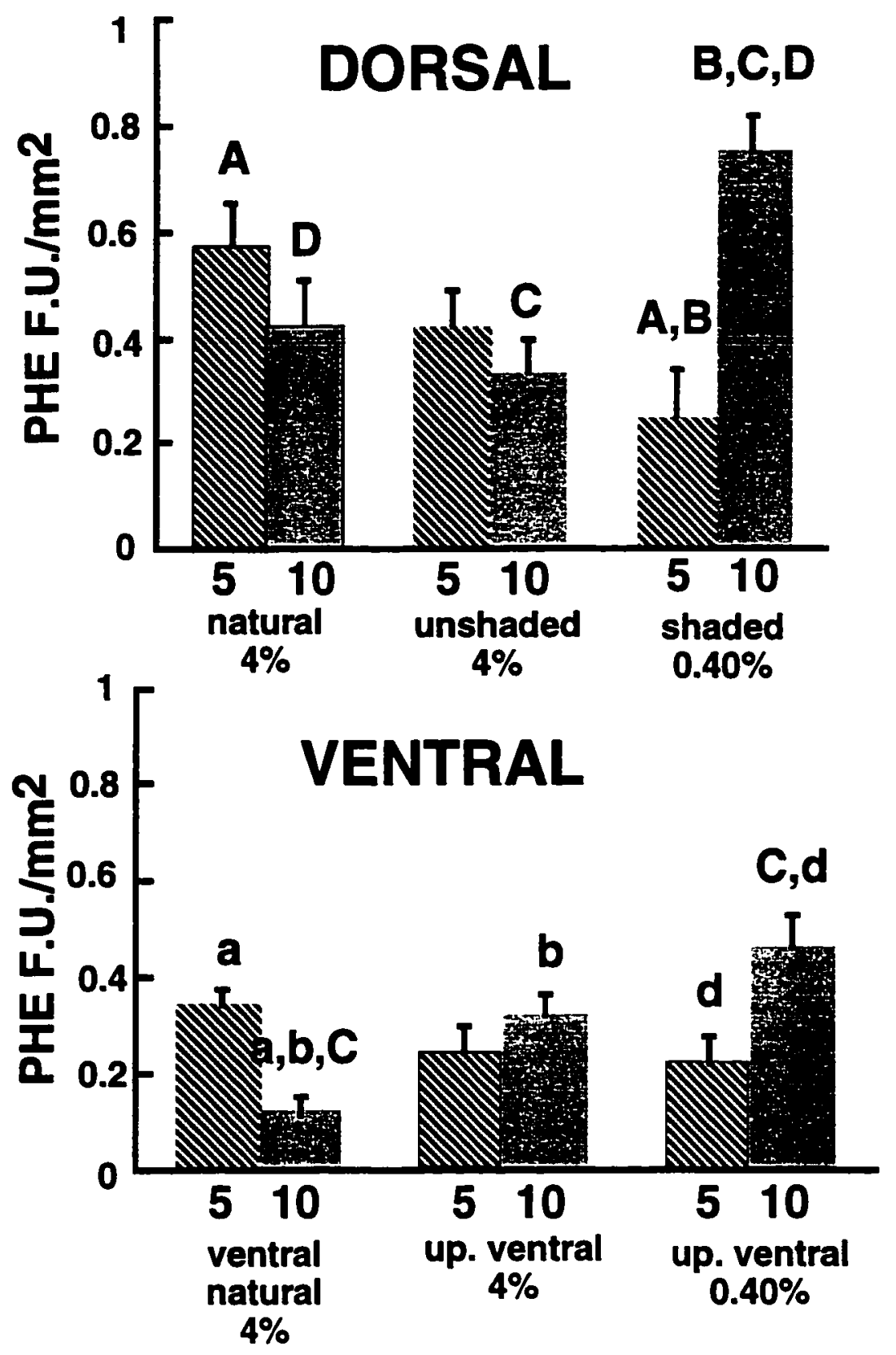

Figure 2. Changes in phycoerythrin fluorescence per $\mathrm{mm}^{2}(\mathrm{X}+$ s.e. $)$ between time [five weeks (5) and ten weeks (10)] and light treatments, [4.0\% of surface irradiance (natural and unshaded plants) and $0.4 \%$ of surface irradiance (shaded plants)] in Bossiella on a $16 \mathrm{~m}$ bench. Similar letters above bars indicate significant differences between treatments (capital letters $=p=0.05$, lower case letters $=p=0.01$, up. ventral $=$ upturned ventral). 

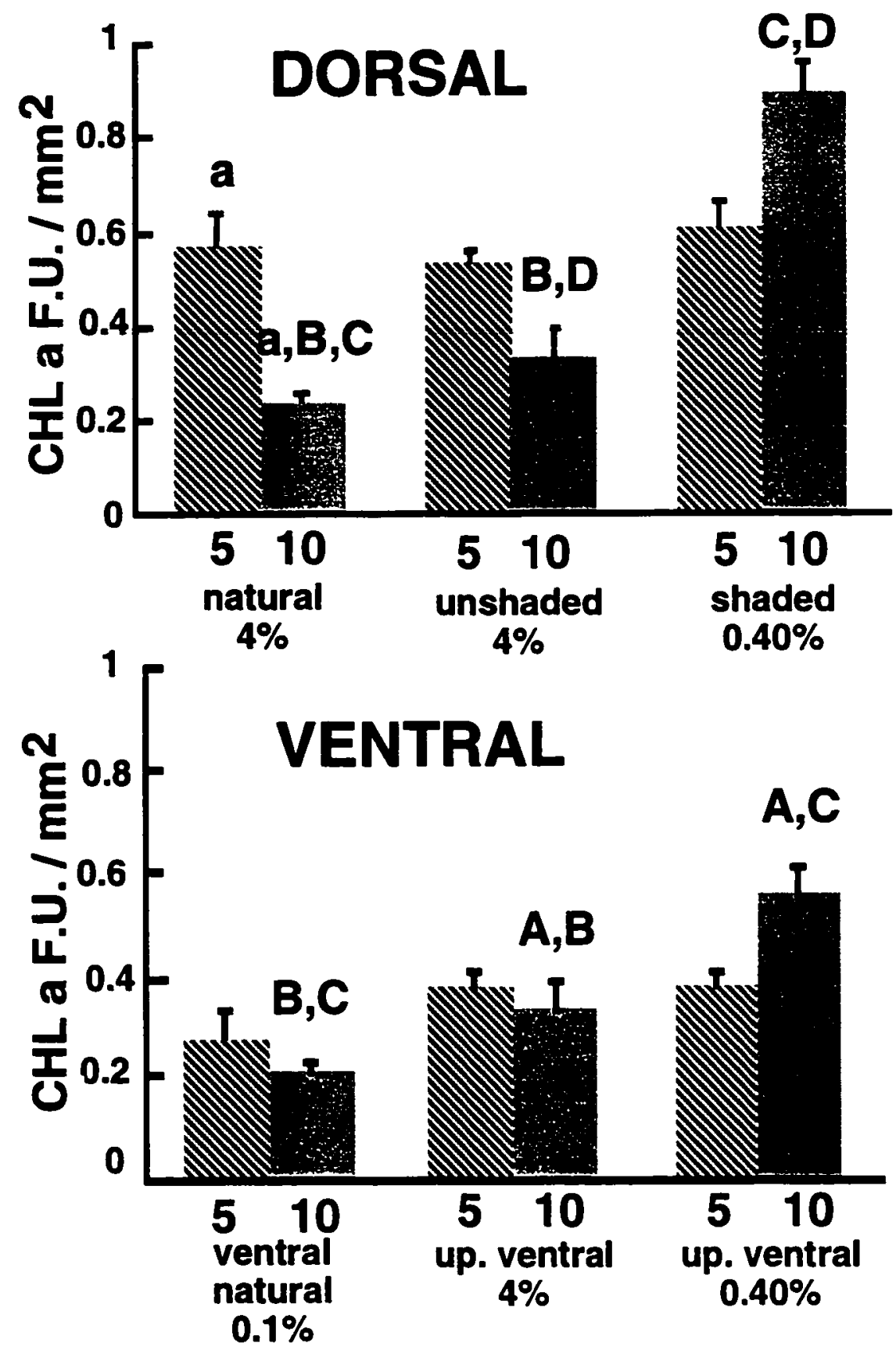

Figure 3. Changes in chlorophyll $a$ fluorescence per $\mathrm{mm}^{2}(\mathrm{X}+$ s.e. $)$ between time [five weeks (5) and ten weeks (10)] and light treatments, [4.0\% of surface irradiance (natural and unshaded plants) and $0.4 \%$ of surface irradiance (shaded plants)] in Bossiella on a $16 \mathrm{~m}$ bench. Similar letters above bars indicate significant differences between treatments (capital letters $=p=0.05$, lower case letters $=p=0.01$, up. ventral $=$ upturned ventral). 


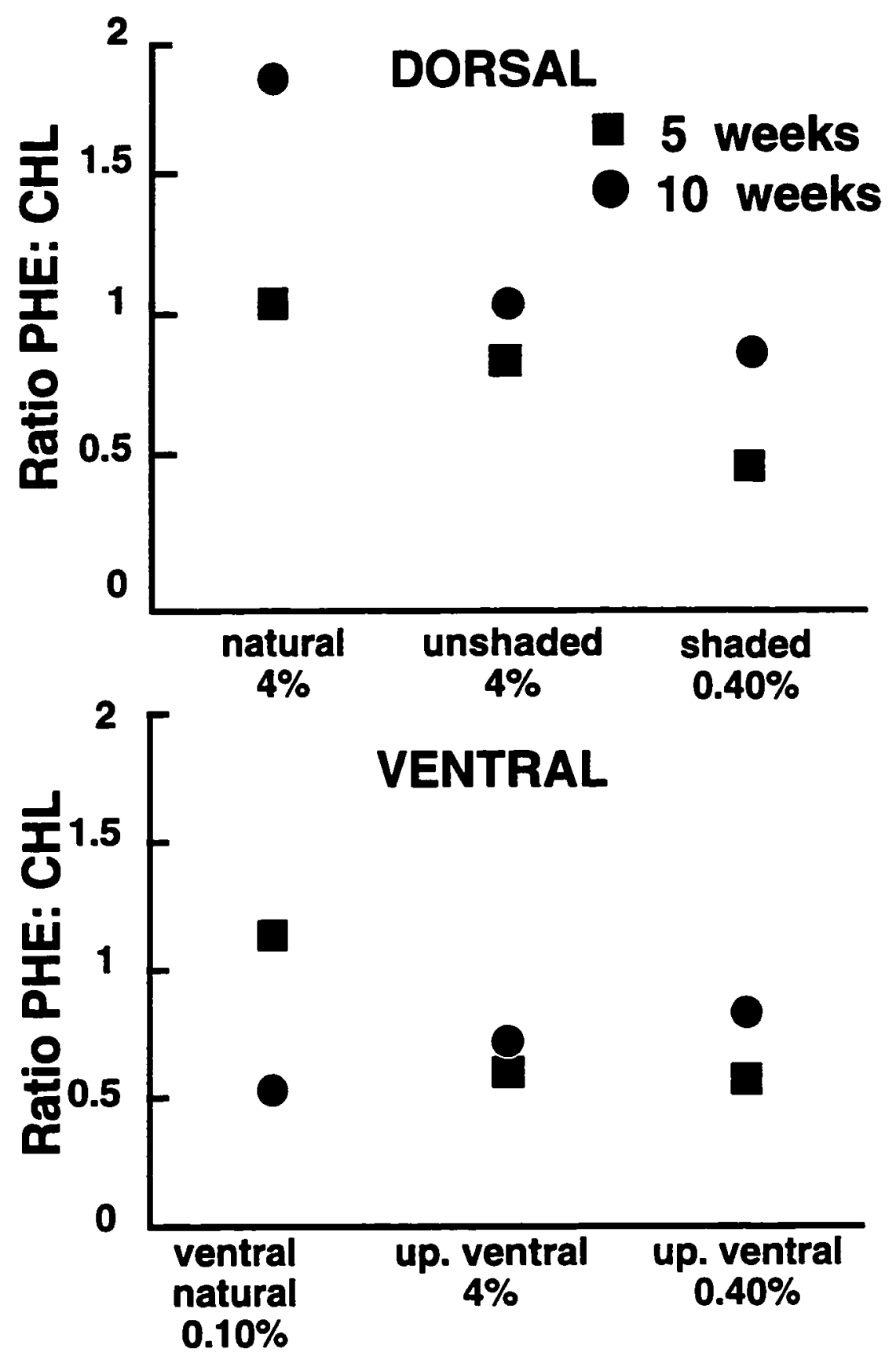

Figure 4. Ratio of phycoerythrin to chlorophyll $a$ (Phe:Chl $a$ ) for two different times. Treatments and surfaces correspond to previously described experiments (see text for explanation). 
Appendix

Molarity and $\mathrm{pH}$ ranges of potassium phosphate $\left(\mathrm{K}_{2} \mathrm{POH}_{4}\right)$ buffer solutions used to extract phycoerythrin from various algal taxa.

\begin{tabular}{|c|c|c|c|}
\hline Reference & Molarity & $\mathrm{pH}$ & Alga \\
\hline Algarra et al. 1991 & $0.10 \mathrm{M}$ & 6.5 & Corallina sp. \\
\hline Beer \& Levy 1983 & $\mathrm{H}_{2} \mathrm{O}$ & 6.8 & Gracilaria sp. \\
\hline Fujita et al. 1985 & $0.01 \mathrm{M}$ & 6.5 & Porphyridium sp. \\
\hline Glazer 1988 & $0.75 \mathrm{M}$ & 6.8 & Rhodophyta \\
\hline Levy \& Gantt 1988 & $0.01 \mathrm{M}$ & 7.0 & Callithamnion sp. \\
\hline Lopez-Figueroa \& Neill 1990 & $0.10 \mathrm{M}$ & 6.5 & Corallina sp. \\
\hline Ohki \& Fujita 1992 & $0.10 \mathrm{M}$ & 6.1 & Phormidium sp. \\
\hline Ramus \& Van der Meer 1983 & $0.10 \mathrm{M}$ & 6.8 & Gracilaria sp. \\
\hline Rosenberg \& Ramus 1982 & $0.05 \mathrm{M}$ & 6.7 & Gracilaria sp. \\
\hline Sivan \& Arad (Malis) 1993 & $0.05 \mathrm{M}$ & 7.0 & Porphyridium sp. \\
\hline Spencer et al. 1981 & $\begin{array}{l}0.05 \mathrm{M} \\
0.01 \mathrm{M}\end{array}$ & $\begin{array}{l}7.0 \\
7.0\end{array}$ & $\begin{array}{l}\text { Callithamnion sp. } \\
\text { " }\end{array}$ \\
\hline Stewart \& Farmer 1984 & Lysozyme & 5.0 & $\begin{array}{l}\text { Cyanobacteria, } \\
\text { Cryptophyta }\end{array}$ \\
\hline Yu et al. 1981 & $0.05 \mathrm{M}$ & 7.0 & Callithamnion sp. \\
\hline
\end{tabular}

